Research

Open Access

\title{
Cooling and hemodynamic management in heatstroke: practical recommendations
}

\author{
Abderrezak Bouchama ${ }^{1}$, Mohammed Dehbi ${ }^{1}$ and Enrique Chaves-Carballo ${ }^{2,3}$
}

\begin{abstract}
1Department of Comparative Medicine MBC-03, King Faisal Specialist Hospital \& Research Centre, P.O. Box 3354, Riyadh 11211, Saudi Arabia 2Department of Neurosciences MBC-76, King Faisal Specialist Hospital \& Research Centre, P.O. Box 3354, Riyadh 11211, Saudi Arabia

${ }^{3}$ Departments of Pediatrics and History and Philosophy of Medicine, Kansas University Medical Center, Kansas, USA
\end{abstract}

Corresponding author: Abderrezak Bouchama, abouchama@kfshrc.edu.sa

Received: 3 Feb 2007 Revisions requested: 23 Mar 2007 Revisions received: 12 Apr 2007 Accepted: 12 May 2007 Published: 12 May 2007

Critical Care 2007, 11:R54 (doi:10.1186/cc5910)

This article is online at: http://ccforum.com/content/11/3/R54

(c) 2007 Bouchama et al.; licensee BioMed Central Ltd.

This is an open access article distributed under the terms of the Creative Commons Attribution License (http://creativecommons.org/licenses/by/2.0), which permits unrestricted use, distribution, and reproduction in any medium, provided the original work is properly cited.

\begin{abstract}
Introduction Although rapid cooling and management of circulatory failure are crucial to the prevention of irreversible tissue damage and death in heatstroke, the evidence supporting the optimal cooling method and hemodynamic management has yet to be established.
\end{abstract}

Methods A systematic review of all clinical studies published in Medline (1966 to 2006), CINAHL (Cumulative Index to Nursing \& Allied Health Literature) (1982 to 2006), and Cochrane Database was performed using the OVID interface without language restriction. Search terms included heatstroke, sunstroke, and heat stress disorders.

Results Fourteen articles reported populations subjected to cooling treatment for classic or exertional heatstroke and included data on cooling time, neurologic morbidity, or mortality. Five additional articles described invasive monitoring with central venous or pulmonary artery catheters. The four clinical trials and 15 observational studies covered a total of 556 patients. A careful analysis of the results obtained indicated that the cooling method based on conduction, namely immersion in iced water, was effective among young people, military personnel, and athletes with exertional heatstroke. There was no evidence to support the superiority of any one cooling technique in classic heatstroke. The effects of non-invasive, evaporative, or conductive-based cooling techniques, singly or combined, appeared to be comparable. No evidence of a specific endpoint temperature for safe cessation of cooling was found. The circulatory alterations in heatstroke were due mostly to a form of distributive shock associated with relative or absolute hypovolemia. Myocardial failure was found to be rare.

Conclusion A systematic review of the literature failed to identify reliable clinical data on the optimum treatment of heatstroke. Nonetheless, the findings of this study could serve as a framework for preliminary recommendations in cooling and hemodynamic management of heatstroke until more evidencebased data are generated.

\section{Introduction}

Heatstroke is a life-threatening condition characterized by a rapid increase in core temperature to more than $40^{\circ} \mathrm{C}$ and widespread, multiple organ tissue injury. It is a leading cause of mortality and neurologic morbidity when there is an unaccustomed and sustained increase in climatic temperature [14]. During the heat wave that affected Europe in August 2003, there were 14,800 victims in France alone, and 4,277 (28.9\%) of these victims were diagnosed as having heatstroke, hyperthermia, or dehydration [4]. As sophisticated climate models predict an increased frequency and severity of heat waves, the incidence of heatstroke with an outcome of mortality or neuro- logic morbidity is expected to rise if proactive measures are not taken $[5,6]$. Heatstroke occurs in epidemic form during heat waves, and both hospital emergency department visits and intensive care unit (ICU) admissions increase sharply. Health care professionals should be adequately prepared to promptly recognize and treat this life-threatening illness.

Laboratory studies using cell lines and animal models have established that heat directly induces tissue injury and that the severity of tissue injury and cell death is a function of the degree and duration of hyperthermia [7-10]. Clinical studies have shown that death from heatstroke mostly occurs soon after the onset of hyperthermia and associated cardiovascular failure [11-14]. Up to one third of those victims who survive

$\overline{\mathrm{BCU}}=$ body cooling unit; $\mathrm{CVP}=$ central venous pressure; $\mathrm{ICU}=$ intensive care unit. 
these initial deleterious effects progress to multi-organ system failure culminating in death or severe neurologic damage $[15,16]$. The most important objectives in the treatment of heatstroke are, therefore, to decrease body temperature as quickly as possible and to support the cardiovascular system. Achievement of these goals is crucial to the prevention of irreversible organ damage and death.

Effective dissipation of heat is accomplished by increasing the temperature gradient (conduction), water vapor pressure (evaporation), and velocity of air (convection) between the skin and the surrounding air $[1,17]$. Several techniques have been devised based on these principles, including immersion in cold water, placement of cold packs or ice slush over parts of or the whole body, the use of cooling blankets, and wetting the body surface while continually fanning [16-30]. These cooling techniques have been used for decades, but the evidence supporting their safety and effectiveness in rapidly reaching a safe body temperature and reducing morbidity and mortality has yet to be evaluated.

Acute circulatory failure is found in $20 \%$ to $65 \%$ of patients with heatstroke and has been implicated in the aggravation of tissue injury and cell death $[12,13,16,31,32]$. The cause of this failure is not well understood but has been attributed variously to pooling of blood into the cutaneous circulation [31], volume loss by evaporation and insufficient intake of fluid [14,31], myocardial damage [13,33], and distributive shock resembling that of sepsis [34]. Accordingly, several treatment modalities have been proposed without adequate supporting evidence $[1,14,34-36]$. The objective of this report is to present a systematic review of the literature which addresses these central phases of care, for the purpose of developing evidence-based practice guidelines for cooling and hemodynamic support in heatstroke, especially classic heatstroke.

\section{Materials and methods Search strategy}

We searched the National Library of Medicine's Entrez PubMed databases for the period 1966 to April 2006, the CINAHL (Cumulative Index to Nursing \& Allied Health Literature) for the period 1982 to April 2006, the Cochrane Database of Systematic Reviews, and the Cochrane Central Register of Controlled Trials Register using the OVID interface. We also manually searched reference lists. The retrieved references were downloaded into a reference manager database, EndNote ${ }^{\circledR}$ version 9 (Thomson, Philadephia, PA/USA). The search was limited to human studies without language restriction and used the $\mathrm{MeSH}$ (Medical Subject Heading) terms heatstroke, sunstroke, and heat stress disorders.

\section{Selection criteria}

Two of the authors independently evaluated the retrieved articles and made selections based on the population, intervention, outcome, and study design.

\section{Cooling methods}

We examined adult and pediatric populations who had classic or exertional heatstroke and who were subjected to cooling treatment in studies that reported cooling time and neurologic morbidity or mortality as endpoints. To be eligible for review, the study had to report original data and consist of randomized controlled studies or observational studies (cohort or descriptive studies, case-control, and case series) involving more than 10 patients.

Exclusion criteria included (a) studies reporting only biochemical and/or immunological endpoints (that is, clinical chemistry, hormones, cytokine levels, and immune cell responses), (b) heat stress disorders (that is, occupational or induced wholebody hyperthermia), (c) reviews, case reports, and case series of fewer than 10 patients, and (d) experimental studies using healthy volunteers or animal models.

\section{Hemodynamic management}

Adult and pediatric populations with classic or exertional heatstroke who were monitored invasively with central venous or pulmonary artery catheters and reporting right- or left-filling pressures or cardiac output as endpoints were examined. To be eligible, the studies must have reported original data in more than five patients.

\section{Endpoints and definitions}

Heatstroke is defined as a core body temperature rising to more than $40^{\circ} \mathrm{C}$ and central nervous system abnormalities such as delirium, convulsions, and/or coma resulting from exposure to a high environmental temperature (classic or nonexertional heatstroke) or strenuous physical exercise (exertional heatstroke). Table 1 presents common and distinctive features of classic and exertional heatstroke [1]. Cooling is defined as physical methods or pharmacologic agents aimed at accelerating cooling to a predefined target temperature. Neurologic morbidity is defined as sustained central nervous system abnormalities such as delirium, convulsions, and coma following cooling and/or during long-term follow-up in survivors.

\section{Results \\ Search results}

The search identified 926 papers on heat illnesses. From these, four randomized controlled studies [26,28-30] and 10 observational studies met the eligibility criteria for the evaluation of cooling methods $[16,18-, 27]$. Seven studies that used cooling method based on conduction were identified, five on evaporation and two on pharmacologic cooling. Various target temperatures ranging from $37^{\circ} \mathrm{C}$ to $40.1^{\circ} \mathrm{C}$ for safe discontinuation of cooling were used. Five observational studies met the criteria for the assessment of hemodynamic management [31,34,37-39]. The total number of patients reported in these 19 publications was 556 , and these were subjected to further analysis (Tables 2, 3, 4, 5, 6). 


\begin{tabular}{lcc}
\multicolumn{1}{l}{ Common and distinctive features of classic and exertional heatstroke } & Exertional \\
\hline \multicolumn{1}{c}{ Features } & Classic & $>40^{\circ} \mathrm{C}$ \\
\hline Common & $>40^{\circ} \mathrm{C}$ & Delirium, convulsion \\
Hyperthermia & Delirium, convulsion & Unknown \\
Central nervous system alteration & $20 \%-30 \%$ & Young \\
Hypotension & & Hot, profuse sweating \\
Distinctive & Elderly & Severe \\
Age & Hot, dry & Common \\
Skin & Mild/moderate & Severe \\
Rhabdomyolysis & Uncommon & Hypoglycemia \\
Renal failure & Mild/moderate & Severe
\end{tabular}

\section{Cooling methods based on conduction}

Conduction is the passive transfer of heat from the body into the surroundings air, liquid, or solid in contact with the skin along a temperature gradient.

\section{Exertional heatstroke} Immersion in iced water

This is the most used conventional cooling technique and involves placing the patient in a tub of iced water and continuously massaging the extremities to promote vasodilatation and heat loss $[11,12,16,19,21]$. Four studies that used this method in patients with exertional heatstroke were identified [19-21,30]. Table 2 presents a summary of data on cooling methods based on conduction in the treatment of exertional heatstroke.

Three of the studies included 41 young military personnel treated with immersion in iced water to a target temperature of between $38.3^{\circ} \mathrm{C}$ and $38.8^{\circ} \mathrm{C}$ [19-21] (Table 2). The cooling time ranged from 10 to 60 minutes in all patients but one. No fatalities were reported. Neurologic morbidity, characterized by marked confusion, violent behavior, and frank psychosis, was present during recovery but subsided subsequently [20].

The fourth study was a prospective comparison of immersion of the torso and thighs in iced water $\left(1^{\circ} \mathrm{C}\right.$ to $\left.3^{\circ} \mathrm{C}\right)$, with evaporative cooling using wet towels and exposure to air at $24.4^{\circ} \mathrm{C}$ without fan ventilation, in hyperthermic long-distance runners [30]. The immersion technique cooled twice as fast as the evaporative technique. Morbidity, mortality, and follow-up were not reported. The assignment of patients to each arm of treatment was not randomized, and the evaporative cooling technique was not optimal (Table 2).
Application of cold packs

One study in which 36 patients were treated with cold packs applied to the whole body was identified. No cooling time was provided, but mortality and neurologic morbidity in survivors were $22.2 \%$ and $11.1 \%$, respectively [18] (Table 2).

\section{Classic heatstroke}

Table 3 presents a summary of data on cooling methods based on conduction in the treatment of classic heatstroke.

\section{Immersion in iced water}

This was applied to 28 patients of a mean age of 71 years (range, 47 to 90 years) with associated comorbid illnesses [16]. The cooling rate achieved was comparable with that of the younger and healthier population described above; however, $14.3 \%$ of the patients died and another $14.3 \%$ sustained severe brain damage. The technique was poorly tolerated and had to be converted to ice massage in some patients, who were not further identified.

\section{Other cooling methods based on conduction}

These included non-invasive and invasive techniques. The former comprised the use of cooling blankets or ice or cold packs covering all or parts of the body, commonly in proximity to large vessels (that is, neck, groin, and axillae) [1]. The invasive techniques consisted of administration of chilled intravenous solution and iced gastric, colonic, bladder, or peritoneal lavage.

A single study that consisted of 39 patients treated with cold packs was identified [24] (Table 2). Thirty-one of the 39 patients had cold packs applied to the axillae and groin and cold wet sheets applied to the trunk; this was combined with 
Table 2

Summary of data on cooling methods based on conduction in the treatment of exertional heatstroke

\begin{tabular}{|c|c|c|c|c|c|c|}
\hline $\begin{array}{l}\text { Study } \\
\text { (country, year) }\end{array}$ & Population & Study design & Intervention & Outcomes measured & Results & Limitations \\
\hline [18] (Israel, 1967) & $\begin{array}{l}\text { Exertional heatstroke } \\
(n=36)\end{array}$ & Case series & $\begin{array}{l}\text { Ice-filled rubber } \\
\text { bottles over the } \\
\text { whole body; cool air- } \\
\text { conditioned room; } \\
\text { target } T_{\text {rect }} \text { : not given }\end{array}$ & Mortality; morbidity & $\begin{array}{l}\text { Mortality: } 22.2 \% \text {; } \\
\text { neurologic morbidity: } \\
11.1 \%\end{array}$ & $\begin{array}{l}\text { Patients enrolled } \\
\text { over 10-year period; } \\
\text { no cooling time } \\
\text { provided; cooling } \\
\text { performed in } \\
\text { different centers }\end{array}$ \\
\hline [19] (U.S., 1975) & $\begin{array}{l}\text { Exertional heatstroke } \\
(n=15)\end{array}$ & Case series & $\begin{array}{l}\text { lced water } \\
\text { immersion; target } \\
\mathrm{T}_{\text {rect }}: 38.8^{\circ} \mathrm{C}\end{array}$ & Mortality; morbidity & $\begin{array}{l}\text { Mortality: } 0 \% \text {; } \\
\text { neurologic morbidity: } \\
0 \%\end{array}$ & None \\
\hline [20] (U.S., 1975) & $\begin{array}{l}\text { Exertional heatstroke } \\
(n=13)\end{array}$ & Case series & $\begin{array}{l}\text { lced water } \\
\text { immersion; target } \\
\mathrm{T}_{\text {rect }}: 38.3^{\circ} \mathrm{C}\end{array}$ & $\begin{array}{l}\text { Cooling time; } \\
\text { mortality; morbidity }\end{array}$ & $\begin{array}{l}\text { Cooling time: }<60 \\
\text { minutes, } 92.3 \% ; \\
\text { cooling time: }>60 \\
\text { minutes, } 7.7 \% ; \\
\text { mortality: } 0 \% ; \\
\text { neurologic morbidity: } \\
0 \%\end{array}$ & None \\
\hline [21] (U.S., 1979) & $\begin{array}{l}\text { Exertional heatstroke } \\
(n=13)\end{array}$ & Case series & $\begin{array}{l}\text { lced water } \\
\text { immersion; target } \\
\mathrm{T}_{\text {rect: }}: 38.3^{\circ} \mathrm{C} \text { to } \\
38.8^{\circ} \mathrm{C}\end{array}$ & $\begin{array}{l}\text { Cooling time; } \\
\text { mortality; morbidity }\end{array}$ & $\begin{array}{l}\text { Cooling time (range): } \\
10 \text { to } 40 \text { minutes; } \\
\text { myocardial ischemia: } \\
7.7 \% \text {; neurologic } \\
\text { morbidity: } 0 \% \text {; } \\
\text { mortality: } 0 \%\end{array}$ & None \\
\hline [30] (U.S., 1996) & $\begin{array}{l}\text { Exertional heatstroke } \\
(n=21)\end{array}$ & $\begin{array}{l}\text { Randomized } \\
\text { controlled trial }\end{array}$ & $\begin{array}{l}\text { Iced water immersion } \\
\left(1^{\circ} \mathrm{C} \text { to } 3^{\circ} \mathrm{C}\right) \text { torso } \\
\text { and upper legs }(n= \\
14) \text { versus wet towel } \\
\text { and air exposure at } \\
24.4^{\circ} \mathrm{C}(n=7) ; \\
\text { target } \mathrm{T}_{\text {rect }}: 38.2^{\circ} \mathrm{C} \\
\text { to } 40.1^{\circ} \mathrm{C}\end{array}$ & Cooling rate & $\begin{array}{l}\text { Conductive-based } \\
\text { cooling faster than } \\
\text { evaporative }(0.20 \pm \\
0.02 \text { versus } 0.11 \pm \\
\left.0.02^{\circ} \mathrm{C} / \text { minute }\right)\end{array}$ & $\begin{array}{l}\text { Small sample size; } \\
\text { comparability of } \\
\text { baseline } \\
\text { characteristics } \\
\text { undetermined; } \\
\text { randomization } \\
\text { method not } \\
\text { specified; } \\
\text { evaporative } \\
\text { technique } \\
\text { suboptimal }\end{array}$ \\
\hline
\end{tabular}

$\mathrm{T}_{\text {rect }}:$ rectal temperature.

cooling blankets in four patients and with ice water lavage in five patients. The overall mortality rate was $20.5 \%$. A cooling time of less than 60 minutes was achieved in 27 patients $(69 \%)$ with a mortality rate of $15 \%$, whereas in the group with a longer cooling time, the mortality rate was 33\%. Although the difference was not statistically significant, this observation suggests that rapid cooling may be an important determinant of outcome. There were insufficient data to assess the value of invasive cooling techniques.

\section{Cooling methods based on evaporation}

Evaporative cooling is based on the physical principle that the conversion of $1.7 \mathrm{ml}$ of water to a gaseous phase consumes 1 $\mathrm{kcal}$ of heat $[1,11]$. The efficiency of evaporative cooling depends on a high water-vapor pressure gradient accomplished by continuously spraying the skin with water and blowing with hot air to keep it warm $[1,17]$.

Table 3

Summary of data on cooling methods based on conduction in the treatment of classic heatstroke

\begin{tabular}{|c|c|c|c|c|c|c|}
\hline $\begin{array}{l}\text { Study } \\
\text { (country, year) }\end{array}$ & Population & Study design & Intervention & Outcomes measured & Results & Limitations \\
\hline [16] (U.S., 1982) & $\begin{array}{l}\text { Classic heatstroke } \\
(n=28)\end{array}$ & Case series & $\begin{array}{l}\text { lced water } \\
\text { immersion; brisk } \\
\text { massage with ice; } \\
\text { target } \mathrm{T}_{\text {rect }} \leq 38.9^{\circ} \mathrm{C}\end{array}$ & $\begin{array}{l}\text { Cooling time; } \\
\text { mortality; morbidity }\end{array}$ & $\begin{array}{l}\text { Cooling time: }<30 \\
\text { minutes, } 93 \% ; \text { cooling } \\
\text { time: } 30 \text { to } 45 \text { minutes, } \\
7 \% \text {; mortality: } 14.3 \% ; \\
\text { neurologic morbidity: } \\
14.3 \%\end{array}$ & $\begin{array}{l}\text { Patients switched to brisk } \\
\text { massage were not } \\
\text { identified }\end{array}$ \\
\hline [24] (U.S., 1986) & $\begin{array}{l}\text { Classic heatstroke } \\
(n=39)\end{array}$ & Case series & $\begin{array}{l}\text { lce packs to axilla } \\
\text { and groin; cold wet } \\
\text { sheets applied to } \\
\text { torso; ice water } \\
\text { lavage; cooling } \\
\text { blankets; target } \mathrm{T}_{\text {rect }} \text { : } \\
\leq 38.9^{\circ} \mathrm{C}\end{array}$ & $\begin{array}{l}\text { Cooling time; } \\
\text { mortality }\end{array}$ & $\begin{array}{l}\text { Cooling time: }<60 \\
\text { minutes, } 69 \% ; \text { mortality: } \\
15 \% ; \text { cooling time: }>60 \\
\text { minutes, } 31 \% \text {; mortality: } \\
33 \% ;\end{array}$ & $\begin{array}{l}\text { Retrospective assignment } \\
\text { of group; comparability of } \\
\text { the groups at baseline } \\
\text { questionable }\end{array}$ \\
\hline
\end{tabular}

$\mathrm{T}_{\text {rect }}:$ rectal temperature. 
Table 4

\begin{tabular}{|c|c|c|c|c|c|c|}
\hline $\begin{array}{l}\text { Study } \\
\text { (country, year) }\end{array}$ & Population & Study design & Intervention & Outcomes measured & Results & Limitations \\
\hline [25] (U.S., 1986) & $\begin{array}{l}\text { Classic heatstroke } \\
(n=14)\end{array}$ & Case series & $\begin{array}{l}\text { Ice to the lateral } \\
\text { aspect of the trunk } \\
\text { and spraying of tepid } \\
\text { water }\left(40^{\circ} \mathrm{C}\right) ; \text { fan } \\
\text { directed to patients; } \\
\text { massage to torso } \\
\text { and neck; chilled } \\
\text { intravenous solution; } \\
\text { target } \mathrm{T}_{\text {rect }} \leq 39.4^{\circ} \mathrm{C}\end{array}$ & $\begin{array}{l}\text { Cooling time; } \\
\text { mortality; morbidity }\end{array}$ & $\begin{array}{l}\text { Median (range) } \\
\text { cooling time: } 60 \\
\text { minutes (34 to } 89 \\
\text { minutes); mortality: } \\
7.1 \% \text {; neurologic } \\
\text { morbidity: } 0 \%\end{array}$ & $\begin{array}{l}\text { Combination of } \\
\text { several cooling } \\
\text { techniques; relative } \\
\text { contribution of each } \\
\text { difficult to ascertain }\end{array}$ \\
\hline $\begin{array}{l}\text { [27] (Saudi Arabia, } \\
\text { 1987) }\end{array}$ & $\begin{array}{l}\text { Classic heatstroke } \\
(n=25)\end{array}$ & Case series & $\begin{array}{l}\text { Wet gauze sheet } \\
\text { with water at } 20^{\circ} \mathrm{C} \text {; } \\
\text { fan with speed } \\
\text { airflow of } 2.6 \mathrm{~m} / \mathrm{s} \text {; } \\
\text { target } \mathrm{T}_{\text {rect }}: \leq 39^{\circ} \mathrm{C}\end{array}$ & $\begin{array}{l}\text { Cooling time; } \\
\text { mortality; morbidity }\end{array}$ & $\begin{array}{l}\text { Mean (range) cooling } \\
\text { time: } 40.4 \text { minutes } \\
\text { (20 to } 145 \text { minutes); } \\
\text { mortality: } 0 \% ; \\
\text { morbidity: } 24 \%\end{array}$ & No follow-up \\
\hline [22] (Kuwait, 1980) & $\begin{array}{l}\text { Classic heatstroke } \\
(n=18)\end{array}$ & Case series & $\begin{array}{l}\text { Body cooling unit*; } \\
\text { target } \mathrm{T}_{\text {rect }}:<38^{\circ} \mathrm{C}\end{array}$ & $\begin{array}{l}\text { Cooling time; } \\
\text { mortality; }\end{array}$ & $\begin{array}{l}\text { Cooling time: } 26 \text { to } \\
300 \text { minutes; } \\
\text { mortality: } 11.1 \%\end{array}$ & No follow-up \\
\hline [23] (Kuwait, 1981) & $\begin{array}{l}\text { Classic heatstroke } \\
(n=174)\end{array}$ & Case series & $\begin{array}{l}\text { Body cooling unit*; } \\
\text { target } \mathrm{T}_{\text {rect }}:<38^{\circ} \mathrm{C}\end{array}$ & $\begin{array}{l}\text { Cooling time; } \\
\text { mortality; }\end{array}$ & $\begin{array}{l}\text { Mean (range) cooling } \\
\text { time: } 78 \text { minutes ( } 20 \\
\text { to } 180 \text { minutes); } \\
\text { mortality: } 14.9 \%\end{array}$ & No follow-up \\
\hline $\begin{array}{l}\text { [26] (Saudi Arabia, } \\
\text { 1986) }\end{array}$ & $\begin{array}{l}\text { Classic heatstroke } \\
(n=16)\end{array}$ & $\begin{array}{l}\text { Randomized } \\
\text { controlled trial }\end{array}$ & $\begin{array}{l}\text { Evaporative cooling } \\
\text { using body cooling } \\
\text { unit }(n=8) \text { versus } \\
\text { conventional method } \\
\text { (wet gauze sheet } \\
\text { with water at } 25^{\circ} \mathrm{C} \\
\text { and fanning air at } \\
\left.20^{\circ} \mathrm{C}\right)(n=8) \text {; body } \\
\text { cooling unit* } \text {; target } \\
\mathrm{T}_{\text {rect }}: \leq 38.5^{\circ} \mathrm{C}\end{array}$ & $\begin{array}{l}\text { Cooling time; } \\
\text { mortality; morbidity }\end{array}$ & $\begin{array}{l}\text { No significant } \\
\text { difference in cooling } \\
\text { time; no death in } \\
\text { either group; } \\
\text { neurologic morbidity: } \\
25 \% \text { versus } 12.5 \%\end{array}$ & $\begin{array}{l}\text { Small sample size; } \\
\text { randomization } \\
\text { method not } \\
\text { specified; no follow- } \\
\text { up }\end{array}$ \\
\hline
\end{tabular}

$T_{\text {rect }}:$ rectal temperature.

${ }^{*} \mathrm{~A}$ special bed preset to spray atomized water at $15^{\circ} \mathrm{C}$ and warm air at $45^{\circ} \mathrm{C}$ over the whole body surface to keep the wet skin temperature between $32^{\circ} \mathrm{C}$ and $33^{\circ} \mathrm{C}[40]$.

Exertional heatstroke

Other than the study mentioned above [30], no study describing the use of the evaporative cooling technique in exertional heatstroke was found (Table 2).

\section{Classic heatstroke}

Five studies comprising 247 patients treated by evaporative cooling techniques, either conventional or by using a specially designed cooling bed, were identified [22,23,25-27]. Table 4 presents a summary of data on cooling methods based on evaporation in the treatment of classic heatstroke.

\section{Conventional evaporative cooling}

This consists of applying gauze sheets wetted with water at $20^{\circ} \mathrm{C}$ to $40^{\circ} \mathrm{C}$ and fanning air at room temperature. In a case series of 14 patients of a mean age of 66 years and who had associated comorbid illnesses, cooling by evaporation using water at $40^{\circ} \mathrm{C}$ and fan ventilation enabled cooling in 34 to 89 minutes, with only one fatality and no morbidity in survivors [25]. In this study, the evaporative method was combined with conductive techniques, namely cooling blanket, gastric, colonic and bladder lavage with iced saline, and intravenous administration of chilled solutions; thus the relative contribution of each modality was difficult to assess.
In another series ( $n=25$ patients) using a similar method but applying wet gauze at $20^{\circ} \mathrm{C}$, the cooling time ranged from 20 to 145 minutes, with no mortality. Six $(25 \%)$ patients progressed to dysfunction of one or more organs with no further follow-up [27].

Evaporative cooling using body cooling unit

The body cooling unit (BCU) is a bed specially constructed to combine spraying of atomized water at $15^{\circ} \mathrm{C}$ and blowing of hot air at $45^{\circ} \mathrm{C}$ over the whole body surface to keep the wet skin temperature between $32^{\circ} \mathrm{C}$ and $33^{\circ} \mathrm{C}$ [40]. The BCU has been used extensively during the Muslim pilgrimage to Makkah, Saudi Arabia, in the summer months, when the incidence of heatstroke rises markedly [23]. A total of three studies using the BCU were identified $[22,23,26]$ (Table 4).

The first two studies comprised 192 patients suffering from classic heatstroke $[22,23]$. The cooling time to reach a target temperature of $38^{\circ} \mathrm{C}$ ranged from 26 to 300 minutes (mean, 78 minutes). The mortality rate varied between $11.1 \%$ and $14.9 \%$. No neurologic morbidity post-cooling was observed among survivors.

The third was a controlled study that compared conventional evaporative cooling with cooling using the BCU [26]. The 
Table 5

Summary of data on pharmacologic cooling in the treatment of classic heatstroke

\begin{tabular}{|c|c|c|c|c|c|c|}
\hline $\begin{array}{l}\text { Study } \\
\text { (country, year) }\end{array}$ & Population & Study design & Intervention & Outcomes measured & Results & Limitations \\
\hline $\begin{array}{l}\text { [28] (Saudi Arabia, } \\
\text { 1990) }\end{array}$ & $\begin{array}{l}\text { Classic heatstroke } \\
(n=20)\end{array}$ & $\begin{array}{l}\text { Randomized } \\
\text { controlled study }\end{array}$ & $\begin{array}{l}\text { Evaporative cooling } \\
+ \text { dantrolene } 2 \text { to } 4 \\
\mathrm{mg} / \mathrm{kg} \text { IV }(n=8) \\
\text { versus evaporative } \\
\text { cooling alone }(n= \\
12) ; \text { target } \mathrm{T}_{\text {rect }}: \leq \\
38.9^{\circ} \mathrm{C}\end{array}$ & $\begin{array}{l}\text { Cooling time; } \\
\text { mortality; morbidity }\end{array}$ & $\begin{array}{l}\text { Cooling time in the } \\
\text { dantrolene group } \\
\text { lower than control } \\
(49.7 \pm 4.4 \text { versus } \\
69.2 \pm 4.8 \text { minutes; } \\
p<0.01) \text {; no } \\
\text { difference in } \\
\text { morbidity and } \\
\text { mortality }\end{array}$ & $\begin{array}{l}\text { Small sample size; } \\
\text { randomization } \\
\text { method not } \\
\text { specified; } \\
\text { comparability of } \\
\text { baseline } \\
\text { characteristics } \\
\text { questionable }\end{array}$ \\
\hline $\begin{array}{l}\text { [29] (Saudi Arabia, } \\
\text { 1991) }\end{array}$ & $\begin{array}{l}\text { Classic heatstroke } \\
(n=52)\end{array}$ & $\begin{array}{l}\text { Randomized } \\
\text { controlled study }\end{array}$ & 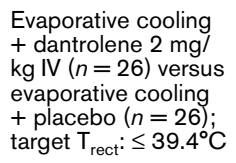 & $\begin{array}{l}\text { Cooling time; organ } \\
\text { dysfunction; length } \\
\text { of hospital stay; } \\
\text { mortality }\end{array}$ & $\begin{array}{l}\text { No significant } \\
\text { difference between } \\
\text { study and control } \\
\text { groups for any of the } \\
\text { endpoints }\end{array}$ & None \\
\hline
\end{tabular}

IV, intravenous; $T_{\text {rect }}:$ rectal temperature.

small sample size precluded any meaningful interpretation of the data.

\section{Cooling methods based on medications}

Dantrolene sodium is a skeletal muscle relaxant that reduces muscular heat produced during abnormally sustained contraction such as observed in malignant hyperthermia and neuroleptic malignant syndrome $[28,29,41]$. It acts directly on the skeletal muscle and is thought to inhibit calcium release from the sarcoplasmic reticulum to the cytosol during sustained contraction and thereby reverses muscle rigidity and decreases production of heat $[41,42]$. Table 5 presents a summary of data on pharmacologic cooling in the treatment of classic heatstroke. Two randomized controlled studies assessed the cooling enhanced pharmacologically by using dantrolene sodium $[28,29]$.

In a randomized study of 20 patients, 2 to $4 \mathrm{mg} / \mathrm{kg}$ dantrolene sodium plus evaporative cooling was found to reduce significantly the cooling time compared with evaporative cooling alone [28]. However, flaws in the study design (namely, a small number of patients and an undefined randomization procedure with the use of different cooling techniques and doses of dantrolene sodium, which were non-blinded to clinicians) raise doubts about the scientific validity of the results.

In contrast, the second study of 52 patients was doubleblinded, randomized, and adequately powered to demonstrate a 30-minute difference in cooling time. This study showed that $2 \mathrm{mg} / \mathrm{kg}$ dantrolene sodium was ineffective in reducing the cooling time, length of hospital stay, and mortality (Table 5) [29].

Antipyretic drugs were used following the findings of increased pyrogenic cytokines during heat stress [1]. These were given to few patients with heatstroke and concomitantly with other cooling techniques, and thus their effectiveness could not be properly assessed [15].

\section{Hemodynamic support}

The hemodynamic response to heat stress has been well studied both in supine, resting, healthy volunteers heated to the limits of thermal tolerance and during exercise in a hot environment [43]. The circulatory adjustments were comparable but differed in magnitude and muscular perfusion, which were more marked for the latter. These changes included a marked increase in cardiac output accompanied by redistribution of blood flow to the cutaneous circulation (up to $50 \%$ of cardiac output) at the expense of renal and splanchnic circulation, while total peripheral vascular resistance remained unchanged [43]. Studies in animal experiments suggest that secondary splanchnic vasodilation mediated by local production of nitric oxide results in cardiovascular collapse and hyperthermia $[44,45]$. In contrast, the hemodynamic alterations that follow heatstroke have not been completely elucidated [31,34,3739].

The search strategy used for this review yielded five studies on the hemodynamic alterations in heatstroke with monitored response to therapy [31,34,37-39]. Table 6 presents a summary of data on hemodynamic monitoring and support in heatstroke.

Hemodynamic alterations in exertional heatstroke

O'Donnell and Clowes [34] performed serial hemodynamic measurements in eight marine soldiers suffering from acute exertional heatstroke. Seven of the patients displayed an elevated cardiac index and low systemic vascular resistance. In one patient, cardiac index was low and systemic and pulmonary vascular resistances were elevated with a marked increase in right atrial pressure (Table 6).

\section{Hemodynamic alterations in classic heatstroke}

By means of right heart catheterization, the hemodynamic profile of 30 elderly patients suffering from classic heatstroke was investigated in three studies [31,37,38] (Table 5). Twentythree $(76.6 \%)$ of the patients exhibited a hyperdynamic profile, 
Table 6

\begin{tabular}{|c|c|c|c|c|}
\hline $\begin{array}{l}\text { Study } \\
\text { (country, year) }\end{array}$ & Population & Intervention & Outcomes measured & Results \\
\hline [34] (U.S., 1972) & $\begin{array}{l}\text { Exertional heatstroke } \\
(n=8)\end{array}$ & $\begin{array}{l}\text { Pulmonary artery catheter; fluid } \\
\text { therapy }\end{array}$ & $\begin{array}{l}\text { Hemodynamic profile; } \\
\text { response to fluid therapy; } \\
\text { mortality }\end{array}$ & $\begin{array}{l}\text { Hyperdynamic profile, } n=7 \\
\text { hypodynamic profile, } n=1 ; \\
\text { optimal response to fluid: } \\
1,200 \text { ml per } 4 \text { hours and } \\
\text { cooling; mortality: } 0 \%\end{array}$ \\
\hline [31] (U.S., 1979) & $\begin{array}{l}\text { Classic heatstroke } \\
(n=7)\end{array}$ & $\begin{array}{l}\text { Pulmonary artery catheter; fluid } \\
\text { therapy }\end{array}$ & $\begin{array}{l}\text { Hemodynamic profile; } \\
\text { response to fluid therapy; } \\
\text { mortality }\end{array}$ & $\begin{array}{l}\text { Hyperdynamic profile, } n=2 \text {; } \\
\text { hypodynamic profile, } n=5 \text {; } \\
\text { failure to respond to fluid: } \\
6,000 \text { ml per } 24 \text { hours and } \\
\text { cooling; no pulmonary edema; } \\
\text { mortality: } 71 \%\end{array}$ \\
\hline [37] (Saudi Arabia, 1989) & $\begin{array}{l}\text { Classic heatstroke } \\
(n=13)\end{array}$ & $\begin{array}{l}\text { Pulmonary artery catheter; fluid } \\
\text { therapy }\end{array}$ & $\begin{array}{l}\text { Hemodynamic profile; } \\
\text { response to fluid therapy; } \\
\text { mortality }\end{array}$ & $\begin{array}{l}\text { Hyperdynamic profile, } n=13 \text {; } \\
\text { fluid } 400 \text { to } 1,200 \text { ml per } 4 \\
\text { hours, } n=8 \text {, no pulmonary } \\
\text { edema; fluid } 1,200 \text { to } 1,800 \mathrm{ml} \\
\text { per } 4 \text { hours, } n=5 \text {, pulmonary } \\
\text { edema; mortality: } 7.6 \%\end{array}$ \\
\hline [38] (Saudi Arabia, 1993) & $\begin{array}{l}\text { Classic heatstroke } \\
(n=10)\end{array}$ & Pulmonary artery catheter & Hemodynamic profile; mortality & $\begin{array}{l}\text { Hyperdynamic profile, } n=8 \\
\text { hypodynamic profile with } \\
\text { normal systemic vascular } \\
\text { resistance, } n=1 ; \\
\text { normodynamic profile, } n=1 \\
\text { mortality: } 10 \%\end{array}$ \\
\hline [39] (Saudi Arabia, 1991) & $\begin{array}{l}\text { Classic heatstroke } \\
(n=34)\end{array}$ & CVP monitoring; fluid therapy & $\begin{array}{l}\text { CVP; response to fluid } \\
\text { therapy; mortality }\end{array}$ & $\begin{array}{l}\text { CVP }<3 \mathrm{~cm} \mathrm{H}_{2} \mathrm{O}, n=12 \\
(35.3 \%) ; \mathrm{CVP} 3 \text { to } 10 \mathrm{~cm} \\
\mathrm{H}_{2} \mathrm{O}, n=16(47 \%) \text {, } \mathrm{CVP}>10 \\
\mathrm{~cm} \mathrm{H}_{2} \mathrm{O}, n=6(17.6 \%) ; \text { fluid } \\
500 \text { to } 2,500 \mathrm{ml} \text { titrated to } \\
\left.\text { CVP (3 to } 8 \mathrm{~cm} \mathrm{H} \mathrm{H}_{2} \mathrm{O}\right) ; \text { optimal } \\
\text { response, no pulmonary } \\
\text { edema; mortality: } 0 \%\end{array}$ \\
\hline
\end{tabular}

CVP, central venous pressure.

and $6(20 \%)$ a hypodynamic profile. The clinical response to fluid therapy and the risk of pulmonary edema varied among studies, thus precluding any meaningful interpretation.

In the last study, the state of hydration and response to a conservative fluid challenge were prospectively assessed with central venous pressure (CVP) monitoring in 34 consecutive patients with classic heatstroke [39]. Twelve patients had a CVP reading of zero or less on arrival, and eight of these patients presented in shock state. Administration of an average of 1 liter ( 0.5 to 2.5 liters) of crystalloids titrated to a CVP of 3 to $8 \mathrm{~cm} \mathrm{H}_{2} \mathrm{O}$ restored an optimal hydration state and did not result in any signs of fluid overload.

\section{Discussion \\ Cooling methods}

The present study evaluated various cooling techniques used to treat heatstroke. We made the following observations:

First, consistent with a previous systematic review, the cooling method based on conduction, namely immersion in iced water started within minutes of the onset of exertional heatstroke, was fast, safe, and effective in young, healthy, and well-trained military personnel or athletes [19-21,30,46]. Furthermore, when extending the analysis to classic heatstroke, this study demonstrated that immersion in iced water of elderly patients suffering from classic heatstroke had a comparable efficacy in achieving a high cooling rate, but the technique was poorly tolerated and was associated with increased morbidity and mortality [16]. These findings concurred with those of earlier studies in which severe shivering, agitation, and combativeness required the mobilization of a large number of staff for restraint and in which sedation was necessary $[11,12,20]$. Other drawbacks reported were poor hygiene (heatstroke is often associated with vomiting and diarrhea) and difficulty both in achieving optimal monitoring and resuscitating unconscious and hemodynamically unstable patients $[11,20]$.

Second, although none of the randomized controlled studies compared evaporative with conductive cooling methods in patients with classic heatstroke, the cooling methods based on evaporation appeared to be less efficient than immersion in iced water in dissipating heat, but they were well tolerated $[22,23,25,26,28,29]$. Despite a slower cooling rate, the mortality rate was low, ranging from $0 \%$ to $14.9 \%$ $[22,23,25,26,28,29]$. For many reasons - such as heterogeneity of the population studied, lack of information on the time required to recognize heatstroke and initiate cooling, and comparability of supportive management - how this favorable outcome compared with that of cooling by immersion in iced water is difficult to ascertain. Until randomized controlled studies comparing these two modalities of cooling treatment are performed, each should be considered an equivalent option in the treatment of classic heatstroke. Perhaps the final choice 
should depend on the patient's condition, the availability of equipment, and the staff's familiarity with the selected technique.

Third, our review showed that non-invasive and well-tolerated cooling modalities, such as ice packs or cold packs, wet gauze sheets, and fan alone or in combination, could represent reasonable alternatives since these are easily applied and readily accessible during epidemic classic heatstroke, when a large number of frail elderly patients are seen in the emergency room [24-27]. Indeed, in four studies, the cooling time using these techniques in patients with classic heatstroke was reasonably low and the outcome was acceptable [24-27].

Fourth, this review suggested that pharmacologic treatment (namely, dantrolene sodium as an adjunct to physical methods to accelerate cooling) was ineffective, whereas antipyretic agents were not properly assessed $[28,29]$. Antipyretics such as aspirin and acetaminophen should be avoided because of their potential to aggravate the coagulopathy and liver injury of heatstroke.

Fifth, our review found no evidence for a specific endpoint temperature at which to halt cooling. A rectal temperature of $39^{\circ} \mathrm{C}$ or less appeared to be safe in terms of mortality in most of the studies, but associated long-term morbidity (particularly neurologic) has not yet been established and further study is required.

\section{Hemodynamic management}

Although rapid and effective cooling is the cornerstone of treatment, the management of circulatory failure in heatstroke is also important [12-14,16]. In an earlier study of 100 patients with classic heatstroke, Austin and Berry [12] showed that hypotension was associated with a mortality rate of $33 \% \mathrm{com}$ pared with $10 \%$ in patients without hypotension. Hart and colleagues [16] found that the necessity for supplementary vasoactive treatment to restore blood pressure was associated with both a high mortality rate and neurologic disability. These observations were reinforced by a recent survey of 345 patients with classic heatstroke which demonstrated that the use of vasoactive drugs within the first 24 hours of admission to the ICU was independently associated with an increased risk of death [32]. These findings established a link between hypotension and poor outcome, suggesting that prevention and treatment of the hemodynamic instability of heatstroke may contribute to improved outcome.

Based on available data, the present study established the following evidence:

The circulatory alterations and collapse in both exertional and non-exertional heatstroke were, for the most part, due to a form of distributive shock characterized by vasodilatation and relative or absolute hypovolemia [31,34,37,38]. A hypodynamic state was observed in approximately $20 \%$ of the patients $[31,38]$. Although myocardial failure appeared only rarely, the presence of myocardial dysfunction at the onset of heatstroke seemed more difficult to ascertain in an elderly population with a high prevalence of pre-existing coronary or structural cardiac diseases $[33,34,47,48]$. Overall, the findings of our study suggested that the hemodynamic profile of heatstroke shares many similarities with sepsis and is consistent with the systemic inflammatory response demonstrated in human and experimental heatstroke $[1,49]$.

In contrast to the findings on the hemodynamic profile, the data on the risk of pulmonary edema were inconclusive. The varying amount of fluid administered in different studies did not explain why some patients developed pulmonary edema and others did not. There were numerous confounding factors such comorbid illness, acute lung injury, and/or heat-related myocardial damage that may be associated with heatstroke and could have accounted for this difference.

Although the present systematic review showed that hypotension could impact negatively on outcome, there was even less evidence to support the concept that restoration of blood pressure would ameliorate the outcome. The findings of this review suggested that besides cooling, the initial hemodynamic management in both exertional and classic heatstroke should include fluid replacement sufficient to restore blood pressure and tissue perfusion. Supporting evidence, however, is lacking for more specific recommendations, such as the selection of a specific type of fluid and the rate and volume of infusion, and so careful fluid replacement is recommended as the incidence of pulmonary edema during resuscitation of heatstroke appeared to be high in some studies [37-39]. Until new evidence is established, the therapeutic approach recommended for hemodynamic management of sepsis can also be applied to heatstroke because of the pathophysiological similarities between the two diseases [50]. Fluid resuscitation should be titrated to clinical endpoints of optimal heart rate, urine output, and blood pressure, and the patients who remain hypotensive after initial fluid and cooling therapy should be considered for invasive hemodynamic monitoring.

\section{Limitations}

This review identified the lack of reliable data from welldesigned controlled studies that address this important phase of emergency treatment of heatstroke, namely cooling and hemodynamic management. Therefore, the findings and recommendations suggested above should be taken cautiously because they were derived mostly from observational caseseries studies without control groups and involved a heterogeneous population, with the probable presence of other confounding factors. 


\section{Future directions}

This study showed that most of the cooling techniques used in the treatment of heatstroke were outdated and rudimentary, whereas a new generation of cooling devices is now available following the findings that induced hypothermia may be beneficial in patients with neurologic injury, particularly post-cardiac arrest [51]. These innovative cooling techniques and devices, which comprise infusion of large volumes of ice-cold crystalloid fluid $\left(4^{\circ} \mathrm{C}\right)$, cooling catheters using ice-cold fluids circulating in a closed circuit, cooling helmets designed to cool the brain, and cold-air or water pads and blankets controlled with sophisticated algorithms, should prove to be of some benefit to patients with heatstroke [51]. However, their efficacy must be rigorously tested in hyperthermic patients and not simply extrapolated from studies on induced hypothermia. Humans regulate heat exchange with the environment by modulating the blood flow through the cutaneous circulation. Indeed, hyperthermia is a high blood flow state due to hypothalamusmediated cutaneous vasodilatation, which is very different from the familiar low blood flow profile observed in post-cardiac arrest $[43,51]$.

In the past decade, there has been substantial advance in the understanding of the mechanisms of heatstroke injury at the molecular and cellular levels [1]. In addition to direct cytotoxicity, it is suggested that heat triggers a complex pathophysiology that involves alteration of heat shock responses, exaggeration of the acute-phase response, and excessive activation of coagulation [1]. Normalizing the body temperature with cooling may not be enough to abrogate the inflammation, coagulation activation, and progression to multiple organ dysfunction and death in more than a third of patients $[1,15,52,53]$. Therefore, in addition to improving the cooling techniques, it is necessary to develop therapy based on modulation of the inflammatory and coagulation responses [5457]. Immunomodulators such as interleukin-1 receptor antagonists, corticosteroids, and recombinant activated protein $\mathrm{C}$ improve survival in the animal model of heatstroke but have yet to be studied in humans [54-57].

\section{Conclusion}

This review revealed the need for more conclusive research aimed at identifying the optimal cooling methods and hemodynamic management of heatstroke. Although the recommendations suggested should be taken cautiously, they were based on a thorough review of the available evidence and hence reflect the current state of knowledge. Until further evidence is established, these could serve as a practical approach for the cooling and hemodynamic management of heatstroke, a condition predicted to become more frequent in epidemic form in the near future.

\section{Competing interests}

The authors declare that they have no competing interests.

\section{Key messages}

- Rapid cooling and management of circulatory failure are crucial to the prevention of irreversible tissue damage and death in heatstroke.

- The literature review failed to identify reliable clinical data on optimum cooling and hemodynamic management of heatstroke.

- Immersion in iced water is effective among young people, military personnel, and athletes with exertional heatstroke.

- No evidence to support the superiority of any one cooling technique in classic heatstroke was found.

- The circulatory alterations in heatstroke were mostly due to a form of distributive shock associated with relative or absolute hypovolemia.

\section{Authors' contributions}

$A B$ made substantial contributions in the conception, design, acquisition, analysis, and interpretation of data. MD participated in the acquisition and analysis of data. EC-C participated in the conception and design of data. All authors drafted and revised the manuscript and have given final approval of the version to be published.

\section{Acknowledgements}

This work was supported in part by the World Health Organization (WHO), Regional Office for Europe, and the EuroHEAT project cofinanced by DG Sanco (Directorate General for Health and Consumer Affairs). WHO, Regional Office for Europe was not involved in any part of the study described in this manuscript.

\section{References}

1. Bouchama A, Knochel JP: Heat stroke. N Engl J Med 2002, 346:1978-1988.

2. Jones TS, Liang AP, Kilbourne EM, Griffin MR, Patriarca PA, Wassilak SG, Mullan RJ, Herrick RF, Donnell HD Jr, Choi K, et al.: Morbidity and mortality associated with the July 1980 heat wave in St. Louis and Kansas City, Mo. JAMA 1982, 247:3327-3331.

3. Semenza JC, Rubin $\mathrm{CH}$, Falter $\mathrm{KH}$, Selanikio JD, Flanders WD Howe HL, Wilhelm JL: Heat-related deaths during the July 1995 heat wave in Chicago. N Engl J Med 1996, 335:84-90.

4. Hemon D, Jougla E: The heat wave in France in August 2003. Rev Epidemiol Sante Publique 2004, 52:3-5.

5. Schar C, Jendritzky G: Climate change: hot news from summer 2003. Nature 2004, 432:559-560.

6. Patz JA, Campbell-Lendrum D, Holloway T, Foley JA: Impact of regional climate change on human health. Nature 2005, 438:310-317.

7. Buckley IK: A light and electron microscopic study of thermally injured cultured cells. Lab Invest 1972, 26:201-209.

8. Overgaard J, Suit HD: Time-temperature relationship in hyperthermic treatment of malignant and normal tissue in vivo. Cancer Res 1979, 39:3248-3253.

9. Adolph EF: Tolerance to heat and dehydration in several species of mammals. Am J Physiol 1947, 151:546-575.

10. Hubbard RW, Bowers WD, Matthew WT, Curtis FC, Criss RE, Sheldon GM, Ratteree JW: Rat model of acute heatstroke mortality. J App/ Physiol 1977, 42:809-816.

11. Ferris EB, Blankenhorn MA, Robinson HW, Cullen GE: Heat stroke: clinical and chemical observations on 44 cases. $J$ Clin Invest 1938, 17:249-261. 
12. Austin MG, Berry JW: Observations on one hundred cases of heatstroke. J Am Med Assoc 1956, 161:1525-1529.

13. Malamud N, Haymaker W, Custer R: Heatstroke: a clinico-pathologic study of 125 fatal cases. Milit Surg 1946, 99:397-449.

14. Levine JA: Heat stroke in the aged. Am J Med 1969, 47:251-258.

15. Dematte JE, O'Mara K, Buescher J, Whitney CG, Forsythe S, McNamee T, Adiga RB, Ndukwu IM: Near-fatal heat stroke during the 1995 heat wave in Chicago. Ann Intern Med 1998, 129:173-181.

16. Hart GR, Anderson RJ, Crumpler CP, Shulkin A, Reed G, Knochel JP: Epidemic classical heat stroke: clinical characteristics and course of 28 patients. Medicine (Baltimore) 1982, 61:189-197.

17. Wyndham $\mathrm{CH}$, Strydom NB, Cooke HM, Maritz JS, Morrison JF, Fleming PW, Ward JS: Methods of cooling subjects with hyperpyrexia. J Appl Physiol 1959, 14:771-776.

18. Shibolet S, Coll R, Gilat T, Sohar E: Heatstroke: its clinical picture and mechanism in 36 cases. Q J Med 1967, 36:525-548.

19. O'Donnell TF Jr: Acute heat stroke. Epidemiologic, biochemical, renal, and coagulation studies. JAMA 1975, 234:824-828.

20. Beller GA, Boyd AE 3rd: Heat stroke: a report of 13 consecutive cases without mortality despite severe hyperpyrexia and neurologic dysfunction. Mil Med 1975, 140:464-467.

21. Costrini AM, Pitt HA, Gustafson AB, Uddin DE: Cardiovascular and metabolic manifestations of heat stroke and severe heat exhaustion. Am J Med 1979, 66:296-302.

22. Khogali M, Weiner JS: Heat stroke: report on 18 cases. Lancet 1980, 2:276-278.

23. Khogali $M$, al Khawashki $M$ : Heat stroke during the Makkah Pilgrimage. Saudi Med J 1981, 2:85-93.

24. Vicario SJ, Okabajue R, Haltom T: Rapid cooling in classic heatstroke: effect on mortality rates. Am J Emerg Med 1986, 4:394-398.

25. Graham BS, Lichtenstein MJ, Hinson JM, Theil GB: Nonexertional heatstroke. Physiologic management and cooling in 14 patients. Arch Intern Med 1986, 146:87-90.

26. Al-Harthi SS, Yaqub BA, Al-Nozha MM: Management of heat stroke patients by rapid cooling at Mecca pilgrimage. Saudi Med J 1986, 7:369.

27. Al-Aska AK, Abu-Aisha H, Yaqub B, Al-Harthi SS, Sallam A: Simplified cooling bed for heatstroke. Lancet 1987, 1:381.

28. Channa AB, Seraj MA, Saddique AA, Kadiwal GH, Shaikh MH, Samarkandi $\mathrm{AH}$ : Is dantrolene effective in heat stroke patients? Crit Care Med 1990, 18:290-292.

29. Bouchama A, Cafege A, Devol EB, Labdi O, el-Assil K, Seraj M: Ineffectiveness of dantrolene sodium in the treatment of heatstroke. Crit Care Med 1991, 19:176-180.

30. Armstrong LE, Crago AE, Adams R, Roberts WO, Maresh CM: Whole-body cooling of hyperthermic runners: comparison of two field therapies. Am J Emerg Med 1996, 14:355-358.

31. Sprung CL: Hemodynamic alterations of heat stroke in the elderly. Chest 1979, 75:362-366

32. Misset B, De Jonghe B, Bastuji-Garin S, Gattolliat O, Boughrara E, Annane D, Hausfater P, Garrouste-Orgeas M, Carlet J: Mortality of patients with heatstroke admitted to intensive care units during the $\mathbf{2 0 0 3}$ heat wave in France: a national multiple-center risk-factor study. Crit Care Med 2006, 34:1087-1092.

33. Zahger D, Moses A, Weiss AT: Evidence of prolonged myocardial dysfunction in heat stroke. Chest 1989, 95:1089-1091.

34. O'Donnell TF Jr. Clowes GH Jr: The circulatory abnormalities of heat stroke. N Engl J Med 1972, 287:734-737.

35. Knochel JP: Environmental heat illness. An eclectic review. Arch Intern Med 1974, 133:841-864.

36. Eichner ER: Treatment of suspected heat illness. Int J Sports Med 1998, 19(Suppl 2):S150-153

37. Al-Harthi SS, El-Deane MS, Akhtar J, Al-Nozha MM: Hemodynamic changes and intravascular hydration state in heat stroke. Ann Saudi Med 1989, 9:378-383.

38. Dahmash NS, Al-Harthi SS, Akhtar J: Invasive evaluation of patients with heat stroke. Chest 1993, 103:1210-1214.

39. Seraj MA, Channa AB, Al-Harthi SS, Khan FM, Zafrullah A, Samarkandi $\mathrm{AH}$ : Are heat stroke patients fluid depleted? Importance of monitoring central venous pressure as a simple guideline for fluid therapy. Resuscitation 1991, 21:33-39.

40. Weiner JS, Khogali M: A physiological body-cooling unit for treatment of heat stroke Lancet 1980, 1:507-509.

41. Britt BA: Dantrolene. Can Anaesth Soc J 1984, 31:61-75.
42. Denborough M: Malignant hyperthermia. Lancet 1998, 352:1131-1136

43. Rowell L: Cardiovascular aspects of human thermoregulation. Circ Res 1983, 52:367-379.

44. Hall DM, Buettner GR, Matthes RD, Gisolfi CV: Hyperthermia stimulates nitric oxide formation: electron paramagnetic resonance detection of NO-heme in blood. J Appl Physiol 1994, 77:548-553.

45. Hall D, Buettner G, Oberley L, Xu L, Matthes R, Gisolfi C: Mechanisms of circulatory and intestinal barrier dysfunction during whole body hyperthermia. Am J Physiol Heart Circ Physiol 2001, 280:H509-521.

46. Smith JE: Cooling methods used in the treatment of exertional heat illness. Br J Sports Med 2005, 39:503-507.

47. Al-Harthi SS, Nouh MS, al-Arfaj $\mathrm{H}$, Qaraquish A, Akhter J, Nouh RM: Non-invasive evaluation of cardiac abnormalities in heat stroke pilgrims. Int J Cardiol 1992, 37:151-154.

48. Shahid MS, Hatle L, Mansour H, Mimish L: Echocardiographic and Doppler study of patients with heatstroke and heat exhaustion. Int J Card Imaging 1999, 15:279-285.

49. Bouchama A, Ollivier V, Roberts G, Al Mohanna F, de Prost D, Eldali A, Saussereau E, El-Sayed R, Chollet-Martin S: Experimental heatstroke in baboon: analysis of the systemic inflammatory response. Shock 2005, 24:332-335.

50. Hollenberg SM, Ahrens TS, Annane D, Astiz ME, Chalfin DB, Dasta JF, Heard SO, Martin C, Napolitano LM, Susla GM, et al.: Practice parameters for hemodynamic support of sepsis in adult patients: 2004 update. Crit Care Med 2004, 32:1928-1948.

51. Bernard $S$, Buist M: Induced hypothermia in critical care medicine: a review. Crit Care Med 2003, 31:2041-2051.

52. Bouchama A, al-Sedairy S, Siddiqui S, Shail E, Rezeig M: Elevated pyrogenic cytokines in heatstroke. Chest 1993, 104:1498-1502.

53. Bouchama A, Bridey F, Hammami MM, Lacombe C, al-Shail E, alOhali $Y$, Combe $F$, al-Sedairy $S$, de Prost D: Activation of coagulation and fibrinolysis in heatstroke. Thromb Haemost 1996, 76:909-915.

54. Chen C, Hou C, Cheng K, Tian R, Chang C, Lin M: Activated protein $C$ therapy in a rat heat stroke model. Crit Care Med 2006, 34:1960-1966.

55. Chiu W, Kao T, Lin M: Interleukin-1 receptor antagonist increases survival in rat heatstroke by reducing hypothalamic serotonin release. Neurosci Lett 1995, 202:33-36.

56. Lin $M$, Liu $H$, Yang $Y$ : Involvement of interleukin-1 receptor mechanisms in development of arterial hypotension in rat heatstroke. Am J Physiol 1997, 273:H2072-2077.

57. Liu $C$, Chien $C$, Lin $M$ : Glucocorticoids reduce interleukin-1 concentration and result in neuroprotective effects in rat heatstroke. J Physiol 2000, 527:333-343. 